University of Tennessee Law

Legal Scholarship Repository: A Service of the Joel A. Katz Library

UTK Law Faculty Publications

2022

Russia's 2020 Constitutional Amendments and the Entrenchment of the Moscow Patriarchate as a Lever of Foreign Policy Soft Power

Robert C. Blitt

Follow this and additional works at: https://ir.law.utk.edu/utklaw_facpubs

Part of the Law Commons 


\title{
Russia's 2020 Constitutional Amendments and the Entrenchment of the Moscow Patriarchate as a Lever of Foreign Policy Soft Power
}

\author{
Robert C. Blitt
}

\section{Contents}

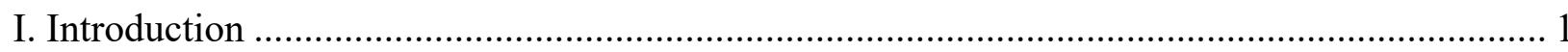

II. The 2020 Constitutional Amendments Augur Significant Implications for Kremlin Foreign

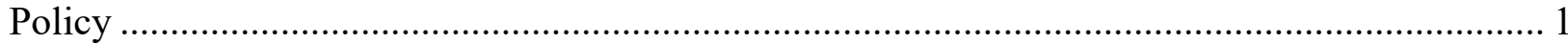

III. The Constitutional Amendments Redouble the Moscow Patriarchate's Central Role as a Kremlin Soft Power Tool............................................................................................... 6

A. Stalwart Advocate of Russian Sovereignty and Multipolarity....................................... 6

B. Guard Dog for Kremlin Truth ................................................................................ 9

C. Global Anchor Point for Cultivating Compatriots ..................................................... 11

D. The Moscow Patriarchate's Crown Jewel: Spreading Traditional Values Everywhere...... 12

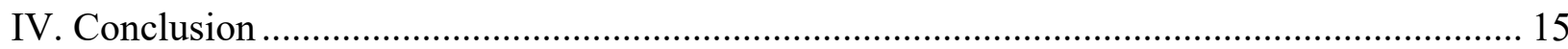




\title{
Russia's 2020 Constitutional Amendments and the Entrenchment of the Moscow Patriarchate as a Lever of Foreign Policy Soft Power
}

\author{
Robert C. Blitt*
}

\section{Introduction}

Much has been written about the Kremlin's embrace of the Russian Orthodox Church-Moscow Patriarchate (ROC) as a lever of soft power for advancing Russia's foreign policy. Based on the substance of the constitutional amendments ratified in July 2020, this chapter reasons that the church-state partnership is poised to grow stronger and more entrenched in the coming years. After briefly highlighting the energizing effect several key constitutional amendments are likely to have on existing Kremlin foreign policy objectives, this chapter offers an assessment of the ROC's central role in disseminating and advocating these newly minted constitutional norms across its international platforms for interreligious, civil society and diplomatic engagement. Given that the constitutional amendments position the Church as an even more vital Kremlin instrument and bless President Vladimir Putin's ability to retain power, ${ }^{1}$ the chapter concludes that policymakers should consider divesting the ROC of its veneer as an autonomous religious actor and adopt measures intended to scrutinize its activities and expose them where necessary as manifestations of Kremlin influence.

\section{The 2020 Constitutional Amendments Augur Significant Implications for Kremlin Foreign Policy}

In January 2020, President Putin surprised Russians and the world by proposing a sweeping set of constitutional reforms. Despite an apparent emphasis on domestic policy and the welfare state, the push for amendments signaled a distinct preoccupation with Russia's international standing. Putin's proposed reforms began by asserting that "Our nation's sovereignty must be unconditional...Russia has returned to international politics as a country whose opinion cannot be ignored."2 Propelled by this outward-facing orientation, Putin's first suggested amendments sought to curb the domestic impact of any decisions taken by international bodies regarding Russia's international obligations.

\footnotetext{
* Toms Foundation Distinguished Professor of Law, University of Tennessee College of Law. This manuscript builds on remarks delivered during a panel discussion on Geopolitics of Religious Soft Power at the 2021 International Studies Association Annual Meeting and reflects a pre-publication version of a chapter that will be appearing in Peter Mandaville (ed.), The Geopolitics of Religious Soft Power: How StATES UsE RELIGION IN Foreign Policy, New York: Oxford University Press, Forthcoming 2022. The author extends thanks to Peter Mandaville for organizing this important project, and to Henry D. Brill and Samantha Buller-Young for their astute editorial assistance.

${ }^{1}$ Vladimir Putin opens door to stay on as Russia's president, DeUTSCH WELLE, Mar. 20, 2020, https://p.dw.com/p/3Z9V5.

${ }^{2}$ Presidential Address to the Federal Assembly, KREMLIN.RU, Jan. 15, 2020, http://en.kremlin.ru/events/president/news/62582.
}

DRAFT - Not for citation without permission of the author. 
Putin's traditional allies were quick to embrace his invitation to propose further amendments. ${ }^{3}$ Among others, Patriarch Kirill, head of the ROC, suggested believers should "pray and work so God would be mentioned in our foundational law...through joint efforts and prayers we will help to ensure that such a lofty idea as faith in God...[is] included in our constitution." " President Putin answered these prayers by endorsing Kirill's proposal and bundling it into the list of revised amendments delivered to the State Duma in March 2020. ${ }^{5}$ Within a matter of days - and with virtually no opposition-Putin's package of amendments secured the approval of Russia's Duma and Federation Council, all 85 regional parliaments, and finally, Russia's Constitutional Court. ${ }^{6}$ In July 2020, citizens overwhelmingly endorsed the 60 pages of amendments in a public vote, ${ }^{7}$ thus blessing the largest overhaul of the Russian constitution since its ratification in 1993.

The approved constitutional amendments cover wide ground, ranging from social and welfare benefits to reorganization of the state's political power structure. But lost in this torrent of reform, certain key amendments - namely those addressing sovereignty, historical truth, Russian compatriots, and traditional values-harbor significant implications for Russian foreign policy.

Perhaps most strikingly, Putin's constitutional amendments offer a muscular assertion of sovereignty aimed at suppressing perceived interference in domestic affairs and invigorating the Kremlin's longstanding campaign for a multipolar international system. ${ }^{8}$ Russia's constitution now enables the Constitutional Court to render unenforceable any international ruling against Russia where the decision is deemed contrary to Russia's constitution. ${ }^{9}$ A still more sweeping amendment enables rejection of foreign or international judicial or arbitral tribunals based on the decidedly more vague - and likely less onerous — standard that the decision conflicts with Russia's public order. ${ }^{10}$

The constitutional amendments prioritizing sovereignty also proclaim that Russia will "tak[e] measures to...prevent interference in the internal affairs of the state." 11 This mandate links up with the Kremlin's promotion of "multipolarity" and provides fresh constitutional cover for repudiating the work of international bodies deigning to "interfere" not only in Russia's internal affairs, but the internal affairs of its allies as well.

\footnotetext{
${ }^{3}$ Robyn Dixon, Putin as Russia's supreme leader? WASHIngton Post, Feb. 23, 2020, https://www.washingtonpost.com/world/europe/putin-as-russias-supreme-leader-constitutional-rewrite-brings-outsome-crazy-ideas/2020/02/23/1e0187ca-4cf6-11ea-967b-e074d302c7d4 story.html.

${ }^{4}$ Patriarch Kirill Proposes Adding Reference to God to Russian Constitution, Feb. 3, 2020, https://orthochristian.com/127683.html. Article 14(1) of the 1993 Russian Constitution specifies that Russia "is a secular state. No state or obligatory religion may be established."

${ }^{5}$ AFP, Putin proposes to enshrine God, heterosexual marriage in constitution, FRANCE 24, Mar. $2,2020$.

${ }^{6}$ http://doc.ksrf.ru/decision/KSRFDecision459904.pdf.

${ }^{7}$ Law of the Russian Federation on amendment to the Constitution of the Russian Federation of March 14, 2020 No. 1-FKZ "On improving the regulation of certain issues of the organization and functioning of public authority", Pub. No. 0001202003140001, http://publication.pravo.gov.ru/Document/View/0001202003140001.

${ }^{8}$ Meeting with members of the working group on drafting proposals for amendments to the Constitution, Feb. 26, 2020, http://en.kremlin.ru/events/president/news/62862.

${ }^{9}$ Law No. 1-FKZ "On improving the regulation of certain issues of the organization and functioning of public authority," supra note 7, at art. 12.

${ }^{10} \mathrm{Id}$., at art. $40(\mathrm{~d})$.

${ }^{11} I d$., at art. 13 .
} 
An additional amendment ensuring the constitutional protection of a particular version of history is inextricably linked to the Kremlin's larger effort to project Russian power and civilization within the international order. President Putin made plain this connection early on during the amendment-drafting period:

We will put a sock in the rotten mouths that some people abroad keep opening to achieve immediate political goals... We will shut them up with true, basic information...[about] our heroes who fell dead defending...the whole world from the brown plague [fascism]. ${ }^{12}$

To validate this decidedly global campaign, Russia's constitution now prohibits questioning Russia's activities during World War II."13 Elevating this "monolithic, triumphalist [historical] narrative" 14 to constitutional imperative will embolden the Kremlin's violation of human rights obligations at home. ${ }^{15}$ At the same time, the constitutional prohibition will enable the Kremlin to amplify its rhetoric targeting non-compliant states. As Putin has already cautioned, those seeking to tarnish Russia's historical reputation are nothing less than "a threat to the fundamental principles of the world order.... Neglecting the lessons of history inevitably leads to a harsh payback." 16

Constitutionalizing a duty to combat falsification positions the Kremlin to open a raft of international challenges, including condoning crimes committed under the Soviet occupation. No less disturbing, leveraging Russia's seat on the United Nations Human Rights Council (UNHRC) to contest sources of factual information risks amplifying the Kremlin's ongoing disinformation (dezinformatsiya) campaigns, ${ }^{17}$ dividing European states, ${ }^{18}$ and undermining the internal stability of vulnerable societies. ${ }^{19}$

Much like the prohibition on falsification, a new amendment expanding support to "compatriots living abroad in the exercise of their rights," 20 is similarly linked to Russia's effort to project

\footnotetext{
12 Putin Says He Rejects Soviet-Style Leaders For Life, RFE/RL, Jan. 18, 2020, https://www.rferl.org/a/russia-sputin-rejects-soviet-style-leaders-for-life/30384778.html.

${ }^{13} \mathrm{http}$ ://duma.gov.ru/en/news/48039/.

${ }^{14}$ Mark Edele, Fighting Russia's History Wars: Vladimir Putin and the Codification of World War II, HISTORY \& MEMORY, Vol. 29, No. 2, Fall/Winter 2017, pp. 90-124, at 109.

${ }^{15}$ See, for example, Luzgin v Russia, European Court of Human Rights, App. No. 17942/17, communicated Sept. 26, 2017, http://hudoc.echr.coe.int/eng?i=001-178086.

${ }^{16}$ Vladimir Putin, The Real Lessons of the 75th Anniversary of World War II, NATIONAL INTEREST, Jun. $18,2020$.

${ }^{17}$ See Elizabeth Grimm Arsenault and Joseph Stabile, Confronting Russia's Role in Transnational White Supremacist Extremism, JustSECURITY.ORG, Feb. 6, 2020, https://www.justsecurity.org/68420/confronting-russiasrole-in-transnational-white-supremacist-extremism/.

${ }^{18}$ Russia's efforts "to distort historical facts and whitewash crimes committed by the Soviet totalitarian regime [are] a dangerous component of the information war...that aims to divide Europe." European Parliament, Resolution on the importance of European remembrance for the future of Europe, Doc. No. P9 TA(2019)0021, Sept. 19, 2019, 1 16.

${ }^{19}$ Media Ajir and Bethany Vailliant, Russian Information Warfare: Implications for Deterrence Theory, STRATEGIC STUDIES QUARTERLY, Vol. 12, No. 3 (Fall 2018), pp. 70-89, 82.

${ }^{20}$ Law No. 1-FKZ "On improving the regulation of certain issues of the organization and functioning of public authority," supra note 7, at art. 1(4).
} 
power abroad. ${ }^{21}$ President Putin's open-ended definition for "compatriots" — asserting "Everyone is Russian outside of Russia, and everyone who speaks Russian and is steeped in Russian culture is entitled to call themselves that"22 — strengthens the Kremlin's case for a larger 'Russian world' (Russkiy Mir) outside of Russia proper. These compatriots, in turn, "amplify Russia's political influence in the former USSR and provide political, economic, and military intelligence" 23 further legitimating Russia's civilizational and great power claims. Enhancing the constitutional status of compatriots in this manner thus reinforces a range of Russia's foreign policy priorities tied to:

- Entrenching Kremlin-friendly media outlets, the ROC, and Russian culture, including the fight for Russian language use;

- Disseminating Russia's official views on history and the fight against falsification; and

- Compounding local societal cleavages and alienation, including by influencing other states" sovereign decisions "without obvious intervention by Russia." 24

Finally, an array of constitutional amendments focusing on traditional values builds up a key ingredient in the Kremlin's post-Yeltsin civilizational identity-building project and its multipolarity campaign. This campaign relies on a narrative wherein only Russia can thwart the West's effort to impose global "ultra-liberalism." In Putin's words, "[E]fforts are being taken today to... destroy the traditional values." 25 This "clash of civilizations" is considered nothing less than a strategic threat to Russia's geopolitical interests:

$[\mathrm{P}]$ romoting the rights of LGBT community and spreading the ideas of radical feminism...dilute[e] the notion of sex identity [and] the values of family and marriage....In fact, the trend is to transform people into...ideal objects for manipulation... [such a] society...is a perfect target for so-called coloured revolutions. $^{26}$

Regarding the amendments themselves, first and perhaps most curiously, Russia's de jure secular constitution now recognizes "faith in God" as a component part of Russia's unifying thousand-

\footnotetext{
${ }^{21}$ Andis Kudors, Russian Soft Power and Non-Military Influence: The View from Latvia, in Mike Winnerstig, ed., Tools of Destabilization: Russian Soft Power and Non-military Influence in the Baltic States, Swedish Defence Research Agency, Doc. FOI-R--3990--SE, Dec. 2014, 110, https://www.foi.se/rapportsammanfattning?reportNo=FOI-R--3990--SE.

${ }^{22}$ Vladimir Putin, Meeting with members of the working group on drafting proposals for amendments to the Constitution, Feb. 26, 2020, http://en.kremlin.ru/events/president/transcripts/62862. Laruelle describes Russian law as defining the term compatriot "in an utterly extensive way." Marlene Laruelle, Russia as a "Divided Nation," from Compatriots to Crimea: A Contribution to the Discussion on Nationalism and Foreign Policy, PROBLEMS OF Post-Communism, 62:2 (2015), 88-97, 94

${ }^{23}$ Vera Zakem, et al., Mobilizing Compatriots: Russia's Strategy, Tactics, and Influence in the Former Soviet Union, CNA.org, Nov. 2015, ii, https://apps.dtic.mil/dtic/tr/fulltext/u2/a626362.pdf.

${ }^{24}$ Anna Bulakh et al., Russian Soft Power and Non-Military Influence: The View from Estonia, in Winnerstig, 35.

${ }^{25}$ Putin Address to World Russian People's Council, Nov. 1, 2018, http://en.kremlin.ru/events/president/news/59013.

${ }^{26}$ Statement by Director of the Foreign Intelligence Service of Russia Sergey Naryshkin at the X International Meeting of High-Level Officials Responsible for Security Matters, June 18, 2019, https://www.mid.ru/en/foreign_policy/international_safety/regprla//asset publisher/YCXLFJnKuD1W/content/id/3704728.
} 
year history. ${ }^{27}$ Without irony, Russia's Human Rights Commissioner Tatyana Moskalkova offered her ringing endorsement of the provision, asserting that the appeal to one god "will not encroach on the views of atheists." 28 Moskalkova's assessment, however, belies how this amendment functions to bless Russia's longstanding - but until now only statutorydiscrimination between so-called traditional and "non-traditional" religions. ${ }^{29}$

A second traditional values amendment makes good on Putin's pledge that "as long as I am President, we will have no 'parent number one' [and 'parent number two'], there will be a father and a mother." 30 The new provision, protecting "the institution of marriage as a union between a man and a woman," 31 signals an escalation of the Kremlin's battle against Russia's LGBTQ community and the international human rights regime. Alongside this targeted anti-LGBTQ measure, a third amendment establishes a more general obligation to ensure policies strengthen protection of the family and preservation of traditional family values. ${ }^{32}$ In practical terms, this provision affords a catchall constitutional impetus for promulgating "family values" legislation likely to exacerbate discrimination and harm by targeting LGBTQ and other families deemed "non-traditional," as well as other vulnerable individuals, including women and minors, living within "traditional" family structures. ${ }^{33}$

Constitutionalizing these "traditional values" in toto paves the way for additional discriminatory legislation $^{34}$ destined to exacerbate the Kremlin's collision course with international human rights mechanisms. But beyond their obvious domestic ramifications, these amendments harbor clear foreign policy implications designed to burnish Russia's bona fides as the vanguard of an anti-West traditional values coalition. ${ }^{35}$ As the next section demonstrates, the ROC is a crucial instrument in building international support for this role.

${ }^{27}$ Law No. 1-FKZ "On improving the regulation of certain issues of the organization and functioning of public authority," supra note 7, at art. 1(2).

${ }^{28}$ Reference to God in Constitution doesn't encroach on atheists' views - ombudsman, INTERFAX, Mar. 3, 2020, http://www.interfax-religion.com/?act=news\&div=15505.

${ }^{29}$ Robert C. Blitt, How to Entrench a De Facto State Church in Russia: A Guide in Progress, 2008 BYU L. Rev. 707 (2008).

${ }^{30}$ Meeting with the working group on drafting proposals for amendments to the Constitution, Kremlin.ru, Feb. 13, 2020, http://en.kremlin.ru/events/president/news/62776.

${ }^{31}$ Law No. 1-FKZ "On improving the regulation of certain issues of the organization and functioning of public authority," supra note 7, at art. 1(7)(d).

${ }^{32}$ Law No. 1-FKZ "On improving the regulation of certain issues of the organization and functioning of public authority," supra note 7, at art. 1(35)(a).

${ }^{33}$ See for example, Nerses Isajanyan, Russia: Decriminalization of Domestic Violence, Law Library of Congress, June 2017, https://tile.loc.gov/storage-services/service/11/1lglrd/2017299008/2017299008.pdf, 5.

34 This legislation already includes an anti-gay "propaganda" law that imposes "hefty fines on same-sex couples who are affectionate in public.” Alina Polyakova, Strange Bedfellows: Putin and Europe's Far Right, WORLD AfFAIRS 177, no. 3 (2014): 36-40, 39, www.jstor.org/stable/43555253.

${ }^{35}$ For example, Russia was one of four non-Organization of Islamic Cooperation (OIC) states that voted against the UNHRC's landmark 2011 Resolution opposing violence and discrimination of the basis of sexual orientation and gender identity (SOGI). Five years later, in its own version of cancel culture, Russia joined a failed attempt to torpedo the UNHRC's endorsement of an Independent Expert on SOGI. Robert C. Blitt, The Organization of Islamic Cooperation's (OIC) Response to Sexual Orientation and Gender Identity Rights: A Challenge to Equality and Nondiscrimination Under International Law, 28 U. IOWA TRANSNAT'L L. \& CONTEMP. ProBS. J. 89 (2018), 160 and 178 . 


\section{The Constitutional Amendments Redouble the Moscow Patriarchate's Central Role as a Kremlin Soft Power Tool}

As Patriarch Kirill reflected in 2016, "it is no longer the West vs. the non-West, but secular liberals vs. adherents of traditional values." 36 To support the Kremlin against this civilizational threat of "mindless multiculturalism" 37 - and to prop up its own vision of Russia as "predestined to be the guardian of global balance, not merely in geopolitical but...in a moral/ethical sense" "38_ the ROC has long committed itself to advocating for the Kremlin's views on each of the constitutional amendments discussed above.

\section{A. Stalwart Advocate of Russian Sovereignty and Multipolarity}

The ROC has consistently reinforced the Kremlin's emphasis on sovereignty and multipolarity. Nearly two decades ago, then Metropolitan Kirill asserted: "Orthodoxy in international politics [can assist] the building up of a multipolar world." 39 This commitment to multipolarity has continued unabated until today, with one Church hierarch going so far as to claim that "One of the consequences of the current coronavirus pandemic could be the real emergence of a multipolar world." 40 The ROC has similarly used its platform to echo the Kremlin's rejection of jurisprudence emerging from the European Court of Human Rights (ECtHR) and other human rights bodies, characterizing it as alien and harmful to Russia's sovereignty. ${ }^{41}$

So pervasive is the Church's commitment to multipolarity and Russian sovereignty that it serves as a leitmotif of sorts, hovering around even the most seemingly innocuous exchanges. For example, when asked about how he passed the time during a flight to the United States, Metropolitan Hilarion, head of the Church's external relations department, replied that he read a book exposing China's plan to replace America as the global superpower. As the self-described representative of a multinational church (rather than a representative of the Russian Federation), Hilarion further opined "If this book had been read in America, it would probably have sobered up those who believe that the main threat to the USA comes from Russia." 42

Church efforts to deflect attention from Russian misadventures builds on a long parallel history of echoing Kremlin disdain for interference in internal affairs of state. In 1999, then Metropolitan Kirill lamented what he called "new forms of confrontation in which...interference in the life of nations have been realized through political and economic actions." ${ }^{43}$ A decade later, the ROC

\footnotetext{
${ }^{36}$ Alicja Curanović, Russia's Mission in the World, Problems of Post-CommunisM, 66:4 (2019), 253-267, DOI: 10.1080/10758216.2018.1530940, 259.

${ }^{37}$ Madeline Roache, 'Liberalism Is Obsolete,' Russian President Vladimir Putin Says Amid G20 Summit, TIME, Jun. 28, 2019, https://time.com/5616982/putin-liberalism-g20/.

${ }^{38}$ Curanović, supra note 36.

39 "View from Russia: The Orthodox Church, State and Europe", Oct. 3, 2005, https://mospat.ru/archive/en/2005/10/27808/.

${ }^{40}$ World Russian People's Council, The Russian Orthodox Church foresees the collapse of globalization and the emergence of a multipolar world due to the pandemic, Apr. 30, 2020, https://vrns.ru/news/5430.

${ }^{41}$ Kristina Stoeckl, The Russian Orthodox Church as moral norm entrepreneur, 44(2) RELIGION, STATE \& SOCIETY 132 (2016), 134

${ }^{42}$ Metropolitan Hilarion: US Secretary of State Pompeo cancelled the meeting an hour before it, under the pressure of ill-wishers, Jul. 11, 2019, https://mospat.ru/en/2019/11/07/news179812/.

${ }^{43}$ Report by Metropolitan Kirill of Smolensk and Kaliningrad, Chairman of the Department for External Church Relations of the Moscow Patriarchate, Dec. 6, 1999, https://mospat.ru/archive/en/1999/12/ne911251/.
} 
adopted a Statement on Growing Manifestations of Christianophobia in the World. While the statement plainly intended to draw attention to discrimination and persecution against Christians, it also explicitly disavowed any intention to "interfere in the internal affairs of state" or to "call the world community to do it."44

The full extent of the ROC's embrace of Kremlin policy in this area, however, is revealed on the occasions when both parties appear willing to set aside their commitment to the principles of sovereignty and non-intervention. For example, the Kremlin has taken an interventionist stance regarding Montenegro's recently enacted Law on Freedom of Religion or Beliefs. ${ }^{45}$ To justify this inconsistency, Russia's Foreign Ministry offered some impressive verbal gymnastics: "The case in point is a sovereign state's law. This is a prerogative of Montenegro and its people. We are categorically against any interference in internal affairs. [But this law] ...could affect the interests of the Metropolitanate of Montenegro... [Therefore], it goes beyond national boundaries and concerns the unity and cohesion of the Orthodox World." 46

The Kremlin's proffered rationale for carving out this exception to non-interference simply doesn't hold water. Rather, it leaves bare the larger campaign to undercut Montenegrin sovereignty and push back against competing western influence in the region. This sense is so acute that President Milo Djukanovic accused Russia of fueling a controversy over the religion law to "undermine [the] country's independence, NATO membership and its attempt to join the European Union." 47

Through this larger lens, it becomes evident that Kremlin intervention-cloaked in ostensible concern for the Orthodox world - serves to advance Russia's interests relating to multipolarity and global status. These decidedly secular motives have not deterred the ROC from serving as the chief vehicle for reiterating the Kremlin's temporal concerns and fueling the tension in Montenegro. Patriarch Kirill dutifully mobilized his high-level diplomacy and media outlets to echo Kremlin attacks on the religious freedom law and the Montenegrin government. From his perspective, events in Montenegro are akin to a "Ukrainian scenario" that encroaches "on canonical Orthodoxy" 48 and accordingly is not subject to the niceties of non-interference. Revealingly, the Patriarch's invocation of a "Ukraine scenario" ties back to the Kremlin's larger concern over Montenegro's political alignment to the West: "The current authorities of Montenegro do not conceal that they are active supporters of eurointegration and isolation from Serbia and for this reason they seek to discredit the common historical spiritual and cultural

\footnotetext{
${ }^{44}$ Russian Orthodox Church Holy Synod's statement on growing manifestations of Christianophibia [sic] in the world, May 30, 2011, https://mospat.ru/en/2011/05/30/news42347/.

${ }^{45}$ Law on Freedom of Religion or Beliefs and Legal Status of Religious Communities, adopted Dec. 24, 2019, https://www.venice.coe.int/webforms/documents/?pdf=CDL-REF(2020)019-e.

${ }^{46}$ Briefing by Foreign Ministry Spokesperson Maria Zakharova, Moscow, Dec. 18, 2019, https://www.mid.ru/en/web/guest/foreign_policy/news/-/asset_publisher/cKNonkJE02Bw/content/id/3961456.

${ }^{47}$ Aleksandar Vasovic, Thousands in Montenegro march against religion law, REUTERS, Feb 29, 2020, https://www.reuters.com/article/us-montenegro-protest-religion-idUSKBN20NOLL. Montenegro's Foreign Ministry flatly accused Moscow of interfering in the country's internal affairs. Protests in Montenegro Carry Into New Year Over Church Bill, RFE/RL, Jan. 20, 2020, https://www.rferl.org/a/protests-in-montenegro-carry-into-new-year-overchurch-bill/30355770.html.

${ }^{48}$ Metropolitan Hilarion of Volokolamsk: We have supported and will support the canonical Church of Montenegro, Aug. 4, 2020, http://www.patriarchia.ru/en/db/text/5672925.html.
} 
heritage of the Serbian and Montenegrin peoples." 49 The prospect of a loss of Russian influence within this tiny country augurs so deep a blow to the Kremlin that the Patriarch has gone so far as to insinuate that Montenegrin officials have subjected Orthodox faithful to torture. ${ }^{50}$

The ROC's readiness to justify Russian interference in Montenegro's internal affairs ${ }^{51}$ surely evidences an inconsistency with respect to its adherence to the doctrine of non-interference. But the constant drumbeat of its propaganda is rendered more sinister because it feeds domestic friction and plants the seeds for potentially more egregious intervention from Moscow. The Kremlin's view that "Unity and solidarity of the Orthodox world... are a condition to ensure normal development of society" 52 gels with the Patriarchate's belief that the Orthodox faithful in Montenegro are inexorably connected to Russia. This fact, coupled with Foreign Minister Sergei Lavrov's declaration that Russia "will always defend the interests of Orthodox Churches" and the freshly minted constitutional imperative to protect an elastic concept of "compatriots" makes the possibility of Russia expanding its compatriot umbrella to all eastern Orthodox believers in the region not altogether far-fetched. At a minimum, it is likely that the target population in Montenegro, egged on by interference from the ROC and Kremlin, will still serve Russia's foreign policy interests by ensuring an environment of domestic political and social instability, within which Moscow can continue to advance its own interests while subverting the West.

The case of Montenegro signals that, like the Kremlin, the ROC will vociferously defend noninterference to shield Russia and its allies from international scrutiny, but quickly discard the norm in service of Russia's foreign interests. Syria provides another case in point. Prior to Moscow's own direct military involvement beginning in 2015, the Kremlin worked tirelessly to foreclose effective international intervention through the UN Security Council, including after the Assad regime's use of chemical weapons. ${ }^{53}$ Russia premised its opposition to UN-sanctioned intervention on the basis of non-interference. ${ }^{54}$ The ROC staked out a similar view disfavoring international intervention, but dramatically changed its tune with Putin's surprise decision to deploy Russian forces to Syria in late 2015. The protection of co-religionist Orthodox faithful and the projection of Russian influence proved so powerful an elixir, that the ROC urged other states to join what it called a "holy war." 55 Indeed, the Church's deafening silence in the face of credible reporting on civilian deaths in Syria due to Russian military operations ${ }^{56}$ most revealingly betrays the extent of its backing for the Kremlin's view of sovereignty and noninterference. With this complicity, the message communicated to its estimated 100 million

\footnotetext{
${ }^{49}$ Archbishop Leonid of Vladikavkaz and Alania, Montenegro authorities prosecute Orthodox Church according to Ukrainian scenario, May 25, 2020, http://www.patriarchia.ru/en/db/text/5641535.html.

${ }^{50}$ Statement of Patriarch Kirill of Moscow and All Russia on the developments in Montenegro, Jul. 13, 2020, http://www.patriarchia.ru/en/db/text/5662894.html.

${ }^{51} \mathrm{https}: / /$ www.rt.com/russia/494869-montenegro-church-crackdown-patriarch/.

${ }^{52} \mathrm{https}: / /$ tass.com/society/1105033.

${ }^{53}$ UN Security Council, Resolution 2118 (2013), UN Doc. S/RES/2118 (2013).

${ }^{54}$ For example, see UN, Security Council Fails to Adopt Draft Resolution Condemning Syria's Crackdown on AntiGovernment Protestors, Owing to Veto by Russian Federation, China, UN Doc. SC/10403, Oct. 4, 2011, https://www.un.org/press/en/2011/sc10403.doc.htm.

${ }^{55}$ Russia's Patriarch Kirill urges 'holy war' on terror, BBC NEws, Oct. 19, 2016, https:/www.bbc.com/news/av/world-europe-37702914/russia-s-patriarch-kirill-urges-holy-war-on-terror. The Patriarch's statement was subsequently retracted.

${ }^{56}$ For example, see Report of the Independent International Commission of Inquiry on the Syrian Arab Republic (Advanced Unedited Version), UN Doc. A/HRC/44/61, Jul. 2, 2020, $\uparrow 40$.
} 
Orthodox faithful, to compatriots abroad, and across its global interfaith and diplomatic networks is plain: Russian sovereignty, influence, and projection of power comes first.

\section{B. Guard Dog for Kremlin Truth}

The ROC has consistently echoed the Kremlin's preoccupation with the threat posed by "falsification" of history. ${ }^{57}$ During the late 2000s, Church clergy leveled accusations of falsification at Ukraine's government, mirroring similar Kremlin actions. ${ }^{58}$ Building on this shared mission, the Ministry of Foreign Affairs and ROC pledged in 2010 to continue their "joint efforts to combat the falsification of history." 59 With falsification now constitutionally prohibited, the Kremlin is likely to continue relying on the Church's unique position to legitimize its branding of those who question the Soviet Union's legacy as enablers of fascism. Already in early 2020, Sergei Lavrov proclaimed that Russia's "diplomatic service will continue to do its best to counter attempts to falsify history [through] close cooperation with the Russian Orthodox Church and other traditional religions." 60

The Moscow Patriarch has taken this cooperative role to heart, marshalling its resources to fiercely reject any position that challenges the Kremlin's narrative of unsullied Russian supremacy. As part of this effort, the Church advocates within the compatriot community abroad to preserve historical memory and oppose attempts to distort history. ${ }^{61}$ But more broadly, the Church also wields the Kremlin's historical narrative as a carrot and stick, to both build a common framework for potential alliances and also to exert pressure on foreign governments.

For example, the Church recently lauded Croatian officials for restoring a memorial to Soviet soldiers, calling it "one of these profoundly symbolic actions which help preserve historical memory." 62 In contrast, Patriarch Kirill directed a six-minute long harangue ${ }^{63}$ at the Bulgarian president for remarks Kirill deemed "outrages" of historical revisionism that depreciated the primary role of Russian state power and sacrifice. ${ }^{64}$ In particular, the Patriarch took issue with state representatives who downplayed the fact that "the liberation of Bulgaria... was written in bloody letters in the history of Russia.... No political correctness can justify the false historical

\footnotetext{
${ }^{57}$ Robert C. Blitt, One New President, One New Patriarch, and a Generous Disregard for the Constitution: A Recipe for the Continuing Decline of Secular Russia, 43 VANDERBILT J. TRANSNAT'L L. 1337, 1361-1363.

${ }^{58}$ Claire Bigg, Russian Patriarch's Visit Creates Storm In Ukraine, RFE/RL, Jul. 31, 2009, https://www.rferl.org/a/Russian_Patriarchs_Visit_Creates_Storm_In_Ukraine/1789959.html.

${ }^{59}$ Blitt, supra note 57 at 1363.

${ }^{60}$ Foreign Minister Sergey Lavrov's remarks at the opening of the 28th International Educational Christmas Readings, "The Great Victory: Heritage and Inheritors", Jan. 27, 2020, https://www.mid.ru/en/foreign_policy/news/-/asset_publisher/cKNonkJE02Bw/content/id/4005976.

${ }^{61}$ Russian Orthodox Church representatives attend conference of compatriots in Shanghai, Mar. 21, 2019, https://mospat.ru/en/2019/03/21/news171759/.

${ }^{62}$ On the eve of the Victory Day a Russian Orthodox Church hierarch said the Office for the Dead at the memorial to Soviet soldiers in Croatian Ilok, May 9, 2018, https://mospat.ru/en/2018/05/09/news159747/

${ }^{63}$ Moscow Patriarchate, His Holiness Patriarch Kirill met with the President of the Republic of Bulgaria, Mar. 4, 2018, https:/www.youtube.com/watch?v=Lmjv3Mrlj98\&feature=youtu.be.

${ }^{64}$ Kiril Avramov, Orthodox Fury: Not-So-Subtle Politics of Patriarch of Moscow and All Rus, Mar. 23, 2018, THE GLOBE POst, https://theglobepost.com/2018/03/23/russia-bulgaria-patriarch-kirill/.
} 
interpretation. And it is a principal message that the Patriarch addresses to Bulgaria, her leadership and people today." ${ }^{\prime} 5$

Through these actions, the Church continually reinforces the Kremlin's view that Russia's reputation is sacrosanct, and that any perceived slight against it, including the "criminal war on monuments," 66 is tantamount to the glorification of Nazism. Moreover, as in the context of the Kremlin's compatriot policy discussed below, here too the Church can act without the diplomatic fetters that might otherwise bind Russia's Ministry of Foreign Affairs. The Patriarch's action in Bulgaria drives this point home, with one observer concluding that Kirill's remarks "aggressively push[ed] the Russian nationalist agenda in a straightforward style, in a way that even the Russian Foreign Ministry avoids when dealing with what it considers 'friendly' nations." 67

In addition to the Church mirroring the state's conception of historical memory regarding WWII, it also perpetuates the Kremlin's false narrative of Russia as a haven for religious freedom, tolerance, and coexistence. This "falsification"-intended to boost Russia's international image as a civilizational alternative to the West-downplays Russia's current and past human rights abuses, and instead proffers its approach to religious coexistence as an export-ready model for other like-minded states. In echoing this dubious claim, the Church consistently ignores the regime's (and its own) contemporary treatment of "non-traditional" religious groups, while also denying Russia's checkered history of religious persecution. In one speech, for example, Metropolitan Hilarion set aside Russia's ever-increasing antipathy towards Jehovah's Witnesses ${ }^{68}$ its role in the production and dissemination of The Protocols of the Elders of Zion, ${ }^{69}$ and the country's forcible expulsion of Muslim Tatars from Crimea, ${ }^{70}$ to boast: "In Russia there have been no religious wars or religious confrontations in our history. People in our country have been able to find a language of mutual understanding... despite their differences in faith."71 The Kremlin invokes a similarly stilted narrative to bolster Russia's international status. For example, Sergei Lavrov has crowed that Russia "[has] accumulated great experience in ensuring the coexistence of people of various creeds" and "protect[ing] true religious values." 72

\footnotetext{
${ }^{65}$ Patriarch Kirill completes his visit to Bulgarian Orthodox Church, Mar. 5, 2018, http://www.patriarchia.ru/en/db/text/5157784.html.

${ }^{66}$ Briefing by Foreign Ministry Spokesperson Maria Zakharova, Moscow, January 23, 2020, https://www.mid.ru/en/foreign_policy/news/-/asset_publisher/cKNonkJE02Bw/content/id/4004544.

67 Avramov, supra note 64.

${ }^{68}$ Case of Jehovah's Witnesses of Moscow and Others v. Russia, European Court of Human Rights, App. No. 302/02, Judgment (Final), Nov. 22, 2010 (holding Russia violated articles 9 and 11 of the European Convention on Human Rights, inter alia, by dissolving a local chapter, banning its activity, and prohibiting its re-registration.).

${ }^{69}$ Michael Hagemeister, The Protocols of the Elders of Zion in Court: The Bern Trials, 1933-1937, in Esther Webman, ed., The Global Impact of the Protocols of the Elders of Zion: A Century-Old Myth (Routledge, 2011), 243.

70 "Punished Peoples" of the Soviet Union: The Continuing Legacy of Stalin's Deportations, HELSINKI WATCH, Sept. 1991, 38.

${ }^{71}$ Metropolitan Hilarion: It is urgent that a system of protecting Christians against persecution be organized, May 19, 2011, https://mospat.ru/en/2011/05/19/news41800/.

${ }^{72}$ Lavrov: Terrorism has nothing in common with professing true religious values, TASS, Dec. 11, 2015, https://tass.com/politics/843516.
} 


\section{Global Anchor Point for Cultivating Compatriots}

As it continues to hammer home the Kremlin's messages on Russian sovereignty and historical truth, the Church's international footprint also positions it to continue playing a central role in realizing the new constitutional obligations towards compatriots. According to Foreign Minister Lavrov, "The tradition of cooperation between national diplomacy and the [ROC] stretches back into centuries. We are still working hand in hand, helping the Russian diaspora and protecting the rights of Russians who have found themselves far away from the Homeland."73 President Putin similarly has stressed tight church-state cooperation regarding compatriot policy, celebrating the fact that the ROC's "great spiritual exploits know[] no state borders. Her canonical territory extends beyond the confines of Russia. You do much for the support of our compatriots and Orthodox communities abroad."74

The Church's deep involvement with other compatriot-focused organizations confirms its pivotal role in echoing Kremlin messages to this constituency. For example, the World Russian People's Council (WRPC), ${ }^{75}$ essentially a Church-directed NGO, functions as a linchpin compatriotnetworking organization that seeks to bolster Russia's profile and policy preferences abroad, including through UN lobbying. ${ }^{76}$ Similarly, the Church maintains formal cooperation agreements with a range of governmental organizations engaged in compatriot outreach, including Rossotrudnichestvo (the Federal Agency for Compatriots Abroad and International Humanitarian Cooperation) and Russkiy Mir. ${ }^{77}$ The ROC's formal agreements with these actors confirm its position as a central nexus for promoting compatriot activities and connections to Russia, unifying this community under the umbrella of Orthodoxy, and echoing the larger message of a clash between Russian and western civilizations. ${ }^{78}$

Tapping into the Moscow Patriarchate's religious and cultural terroir provides the Kremlin with two significant advantages: First, the Church can promote Kremlin messages without the conventional baggage that attaches to overtly political channels or state-backed propaganda outlets such as RT and Sputnik. Second, because of the Church's sweeping global engagement, the Kremlin can access broader, more diverse constituencies that transcend the narrow realm of

\footnotetext{
${ }^{73}$ Sergei Lavrov, Speech at the XIV World Russian People's Council (May 25, 2010),

${ }^{74}$ Speech by the President of Russia Vladimir Vladimirovich Putin before the Participants of the Episcopal Council of the Russian Orthodox Church, Dec. 1, 2017, https://mospat.ru/en/2017/12/01/news153708/. For a more recent reiteration of the Church's role, see Gathering in honour of the 10th anniversary of the Russian Orthodox Church Local Council and the Patriarch's enthronement, http://en.kremlin.ru/events/president/news/59757.

${ }^{75}$ See https://vrns.ru. Patriarch Aleksii II established the WRPC in 1993 and the organization is currently led by Patriarch Kirill.

${ }^{76}$ Alicja Curanović, The Russian Orthodox Church, Human Security, Migration and Refugees: Concepts, Strategies and Actions, in Lucian N. Leustean, ed, ForCED MigRATION AND HUMAN SECURITY IN THE EASTERN ORTHODOX WORLD (Routledge, 2020), 70.

${ }^{77}$ Under the guise of promoting the Russian language, Russkiy Mir busies itself "strengthening the spiritual unity of the Russian world" and operating as "a bulwark against the threat of globalization." The organization reserves a seat on its board of directors for the Moscow Patriarchate, and also has been accused of serving as "one of the structural divisions of Russia's Foreign Intelligence Service.” Robert C. Blitt, Russia's Orthodox Foreign Policy: The Growing Influence of the Russian Orthodox Church in Shaping Russia's Policies Abroad, 33 U. PA. J. INT'L L., 363, 389-390.

${ }^{78}$ Jarosław Ćwiek-Karpowicz, Limits to Russian Soft Power in the Post-Soviet Area, DGAPanalyse, July 2012 N 8 , 7. See also Cristina Maza, Putin Vows to Rebuild Christian Syria, Restoring Churches and Bringing Refugees Home, NEwSwEEK, Dec. 5, 2017, https://www.newsweek.com/russia-putin-rebuild-christian-syria-churches-735539.
} 
compatriots. This formula - whereby the ROC operates as convenor of compatriots, other clergy, and foreign government officials to discuss inter-religious relations and cooperation with state authorities ${ }^{79}$ - is repeated across the globe, furnishing the Kremlin with a persuasive and seemingly neutral forum for informing worldviews and influencing global and foreign political dynamics.

With the onset of a constitutional obligation to protect compatriots, the Church's role as the Kremlin's spear tip for engagement is poised for expansion. If defending Russian civilization includes the protection of orthodoxy, and compatriots include "individuals who make the free choice of a spiritual, cultural, and legal link to the Russian Federation", it may not be too great a leap to suggest that Moscow may seek to bless Orthodox belief as a basis for passportization. ${ }^{80}$ Such a move could be used to deepen instability, enhance Russian influence, or even to justify direct intervention in the name of Christian communities expressing affinity and support for Russia. ${ }^{81}$ Patriarch Kirill already has sought to inculcate goodwill for such intervention abroad. And the mantle of defending persecuted Christians in Syria continues to resonate for the Kremlin. Expanding on this, the Church's outreach to other Orthodox "compatriots" hints at regions and countries where the Kremlin may seek to expand its influence using Orthodoxy as a bridgehead. The view of Catholicos-Patriarch Nerses Bedros XIX, head of the Armenian Catholic Church, is informative here: "Christians in the Middle East looked at Russia as at their defender and their main hope." 82 From this perspective, the constitutional amendment on compatriots may signal additional fuel for Russian messianism and the Kremlin's framing of the country and its civilization as the last bulwark against a godless world overrun by the corrupting influence of the ultra-liberal West. ${ }^{83}$

\section{The Moscow Patriarchate's Crown Jewel: Spreading Traditional Values Everywhere}

If the constitutional amendments on sovereignty, falsification and compatriots merely portend an enlarged soft power role for the ROC, the amendments entrenching traditional values render this eventuality inescapable. These amendments - directly attributed to the ROC's lobbying ${ }^{84}$ effectively enshrine the Church's function as guardian of Russia's spiritual and moral identity, thus elevating its already central role as a chief exporter of the Kremlin's civilizational vision. In Patriarch Kirill's words: "Mentioning the value of the faith in God in our

\footnotetext{
${ }^{79}$ DECR Chairman presided over round-table conference on cooperation between Russian Church and compatriots living in countries of Middle East and Africa, Nov. 28, 2019, http://www.patriarchia.ru/en/db/text/5539041.html.

${ }^{80}$ Toru Nagashima, Russia's Passportization Policy toward Unrecognized Republics, PROBLEMS OF POSTCommunism, 66:3 (2019), 186-199, DOI: 10.1080/10758216.2017.1388182. Passportization entails "the mass conferral of Russian citizenship on the population of particular territories by distributing Russian passports." Id., at 188. See also Fabian Burkhardt, Russia's "Passportisation" of the Donbas, SWP Comment 2020/C 41 (German Institute for International and Security Affairs), Aug. 3, 2020, doi:10.18449/2020C41.

8150000 Syrian Christians ask for Russian citizenship, INTERFAX, Oct. 16, 2013, http://www.interfaxreligion.com/?act=news\&div=10818.

${ }^{82}$ His Holiness Patriarch Kirill meets with the head of Armenian Catholic Church, Apr. 29, 2015, https://mospat.ru/en/2015/04/29/news118485/.

${ }^{83}$ Dmitry (Dima) Adamsky, Christ-loving Diplomats: Russian Ecclesiastical Diplomacy in Syria, SURVIVAL, $61: 6$ (2019), 49-68, 51.

${ }^{84}$ Metropolitan Hilarion: Transformation of Hagia Sophia into mosque in situation of today would be inadmissible violation of freedom of faith, MosPAT.RU, Jun. 4, 2020, https://mospat.ru/en/2020/07/05/news185295/.
} 
Constitution... solidif[ies] the historical and spiritual continuity of the peoples of our country, who cannot imagine themselves without religion...." 85

More accurately, however, the ramifications of constitutionalizing the collection of traditional values amendments go well beyond a harmless nod to history or religious belief. These values now reflect Kremlin norms of the first order to be spread as the mortar for shoring up multipolarity, sovereignty, and opposition to the looming threat of western "ultra-liberalism". In fact, the Church has portrayed traditional values as under siege for longer than the Kremlin, and in even broader terms that lack any pretense of diplomatic nicety. For example, in 2004 then Bishop Hilarion warned of a brewing clash of civilizations: "It may well be the case that the entire Western civilization, not only in Europe but also elsewhere, is becoming radically antiChristian and anti-religious. In this case there is a need of not only a pan-European but also of a universal common front formed by traditional religious confessions in order to repel the onslaught of militant secularism." 86

To strengthen Russia's hand in this conflict, the Church has established and reinforced alliances with a range of religious constituencies. In addition, it has courted conservative activists, compatriots, simpatico foreign governments, and political operatives. Through these alliances and its own efforts, the ROC staunchly opposes any perceived encroachments on traditional values while simultaneously endorsing the Kremlin's international leadership as the most effective guardian of these values.

In the realm of religious outreach, the Church regularly engages with other "fraternal" churches to project its politics outside Russia. These interactions often seek to undercut western institutions from within. In one visit to Bulgaria - a European Union (EU) member statePatriarch Kirill used a meeting with the Bulgarian Orthodox Church to appeal directly to Bulgarians to reject the EU for imposing "behaviours believed to be sinful by Christians and ethically unnatural." ${ }^{87}$ Similarly, the ROC invokes traditional values to build common ground with other non-Orthodox religious faiths. As one human rights organization concluded, this "unholy alliance" brings together "traditionalist actors from Catholic, evangelical, Mormon....and Muslim faith backgrounds" to "attempt[] to revert feminist and sexual rights gains at the international level." ${ }^{\prime 8}$

\footnotetext{
${ }^{85}$ Patriarch Kirill insists on inserting God reference in Russian constitution, INTERFAX, Mar. 2, 2020, http://www.interfax-religion.com/?act=news\&div=15500.

${ }^{86}$ Bishop Hilarion Alfeyev, Christianity and the Challenge of Militant Secularism, International Conference of the Australian and New Zealand Association of Theological Schools (July 5-8, 2004), http://www.orthodoxytoday.org/OT/view/smart-parenting-xvii-love-and-worship-in-the-domestic-church-of-god.

${ }^{87}$ Fraternal talk between Primates of the Russian and Bulgarian Orthodox Churches, May 27, 2014, https://mospat.ru/en/2014/05/27/news103134/. See also Atanas Slavov, The Bulgarian Orthodox Church - An Instrument For Russian Influence in the Region, BULgaria ANALYTICA, Jun. 28, 2017, https://bulgariaanalytica.org/en/2017/06/28/the-bulgarian-orthodox-church-an-instrument-for-russian-influence-inthe-region/.

${ }^{88}$ Observatory on the Universality of Rights, Rights at Risk: The Observatory on the Universality of Rights Trends Report 2017, May 22, 2017, https://www.awid.org/sites/default/files/atoms/files/rights-at-risk-ours-2017.pdf.
} 
The 2016 Havana Declaration ${ }^{89}$ signed by the ROC and the Vatican exhibits this latter type of outreach $^{90}$ and also illustrates the ROC's use of traditional values as a tacit springboard for endorsing the Kremlin's larger foreign policy ambitions. Seemingly validating Russia's role in Syria as the best hope for its indigenous Christians, the Declaration calls "upon the international community to act urgently...to prevent the further expulsion of Christians from the Middle East." Likewise, the Declaration offers only a generic condemnation of violence in Ukraine, ${ }^{91}$ that coincidentally aligns with the ROC's effort to portray itself (and the Kremlin) as neutral peacemakers in the conflict. By championing these views as shared, the Declaration propels the Vatican "deep into geopolitics" and effectively functions to condone Russia's foreign policy misadventures while simultaneously critiquing the West. ${ }^{92}$ The ROC's effort to win over the Vatican as an international ally is rendered especially transparent when situated alongside parallel Kremlin efforts to secure the same Papal buy-in for Russia's Syria project and its narrative of Russia "as a bulwark of morality and traditional values." 93

Church hierarchs also conduct myriad meetings and working groups with high-level government representatives in Russia and abroad. During these exchanges, Church officials typically reiterate the importance of joint efforts to defend traditional values and protection of the family; ${ }^{94}$ discuss religious cooperation; ${ }^{95}$ stress special ties based on faith and spiritual culture; ${ }^{96}$ raise concerns relating to Christian persecution and "problems of the Russian-Ukrainian relationships," 97 and use traditional values as a wedge to engage other issues typically falling into the realm of bilateral state relations. ${ }^{98}$

The Church's advocacy on behalf of traditional values — and Russian policy — similarly extends to conservative civil society groups across the globe. For example, C-Fam, a U.S.-based selfdescribed "pro-family" NGO, has fawned over the ROC's rejection of a UNICEF brief calling for the elimination of discrimination based on sexual orientation and gender identity. ${ }^{99}$ More explicitly, the International Organization of the Family (IOF) has consistently boosted the

\footnotetext{
${ }^{89}$ Joint Declaration of Pope Francis and Patriarch Kirill of Moscow and All Russia, Havana, Cuba, Feb. 12, 2016, http://www.vatican.va/content/francesco/en/speeches/2016/february/documents/papafrancesco_20160212 dichiarazione-comune-kirill.html and http://p2.patriarchia.ru/2016/02/13/1238676766/eng.pdf.

${ }^{90}$ The meeting was the first of its kind since the Great Schism of 1054 divided eastern and western Christianity.

${ }^{91}$ Joint Declaration of Pope Francis and Patriarch Kirill of Moscow and All Russia, ๆ 26.

${ }^{2}$ Did the pope just kiss Putin's ring?, ThE ECONOMIST, Feb. 15, 2016, https://www.economist.com/europe/2016/02/15/did-the-pope-just-kiss-putins-ring.

${ }^{93}$ Jacopo Barigazzi, Why the Pope P Putin, Politico.eU, Aug. 11, 2017, https://www.politico.eu/article/popefrancis-loves-vladimir-putin-russia-religion/.

${ }^{94}$ Working Group for Dialogue between the Russian Orthodox Church and the Residency of Religious Affairs of the Republic of Turkey takes place, Dec. 16, 2012, https://mospat.ru/en/2012/12/16/news77874/.

${ }^{5}$ Negotiations between Patriarchal Exarch for South-East Asia and Singapore's minister for foreign affairs, Sep. 8, 2020, http://www.patriarchia.ru/en/db/text/5689149.html.

${ }^{96}$ DECR chairman meets with the head of the Greek diplomatic mission in Moscow, Oct. 13, 2020, http://www.patriarchia.ru/en/db/text/5705703.html.

${ }^{97}$ Metropolitan Hilarion of Volokolamsk meets with Ambassadors of Italy, France, Great Britain, Greece, Brazil, Serbia, Bulgaria and Lebanon, Oct. 5, 2020, http://www.patriarchia.ru/en/db/text/5702292.html.

${ }^{98}$ See for example, Bishop Pitirim of Jakarta meets with the head of Indonesian diplomatic mission in Moscow, Sep. 29, 2020, http://www.patriarchia.ru/en/db/text/5699285.html.

${ }^{99}$ Stefano Gennarini, Russian Orthodox Condemn UN Children's Fund For Promoting Homosexuality, C-Fam, Dec. 23, 2014, https://c-fam.org/friday fax/russian-orthodox-condemn-unicef-childrens-fund-for-promotinghomosexuality/.
} 
international status of the ROC and Kremlin in advancing traditional values. Among other things, the IOF has organized its World Congress of Families gatherings ${ }^{100}$ using funding provided by Orthodox oligarch Konstantin Malofeev, ${ }^{101}$ endorsed the need to have Russia play "a very prominent role in the matter of family advocacy and moral values on a global scale,"102 and has celebrated Russia as "the Christian saviors of the world." 103

Through these types of contacts and interactions, the ROC is able to network not only with likeminded civil society, ${ }^{104}$ but to "mingle[] with leaders" from across Europe and "their comrades from the American heartland." "105 Groups like C-Fam and IOF also echo this shared traditional values agenda - replete with its Kremlin-endorsed pro-sovereignty and anti-international human rights law message - in lobbying their own domestic governments. Consider C-Fam's assertion that it "worked for 24 years" to secure U.S. endorsement of the recently signed Geneva Consensus Declaration (GCD) on Promoting Women's Health and Strengthening the Family. ${ }^{106}$ This document, signed by the Trump administration (but subsequently rescinded by the Biden administration), ${ }^{107}$ invoked national sovereignty to reject international protection for the right to abortion and framed women's right to sexual and reproductive health as exclusive of abortion, two hallmarks of the traditional values agenda.

\section{Conclusion}

The constitutional amendments discussed above resonate with implications for Russia's foreign policy. The emphasis on sovereignty, together with the elevation of historical truth, compatriots, and traditional values are all likely to reenergize the Kremlin's global efforts to press for multipolarity as a means of supplanting democratic and liberal values and justifying its relativist war of attrition against the international human rights framework. In addition, given the ROC's longstanding global engagement around these issues, the amendments are further likely to usher

\footnotetext{
${ }^{100}$ Masha Gessen, Family Values: Mapping the spread of antigay ideology, HARPER's, Mar. 2017, https://harpers.org/archive/2017/03/family-values-3/?single=1.

${ }_{101}$ Jason Horowitz, Italy's Right Links Low Birthrate to Fight Against Abortion and Migration, N.Y. TiMES, Mar. 27, 2019, https://www.nytimes.com/2019/03/27/world/europe/italy-verona-salvini-world-congress-of-families.html. ${ }^{102}$ Hannah Gais, In Search of the Russian Soul: How Russia Became the U.S. Far Right's Mirror, The Public EyE (Fall 2019), 7, https://www.politicalresearch.org/sites/default/files/2020-08/ThePublicEye_2019_Fall_nobleeds.pdf. ${ }^{103}$ Natasha Bertrand, 'I really believe that Russia is the leader of the free world right now', BUSINESS INSIDER, Dec. 11, 2016, https://www.businessinsider.com.au/russia-connections-to-the-alt-right-2016-11.

${ }^{104}$ See for example, Mark Silk, The other Russian collusion story, ReLigion News SeRvice, Mar. 25, 2019, https://religionnews.com/2019/03/25/the-other-russian-collusion-story/.

${ }^{105}$ Anne Applebaum, The False Romance of Russia, The AtLANTic, Dec. 12, 2009, https://www.theatlantic.com/ideas/archive/2019/12/false-romance-russia/603433/.

${ }^{106}$ Geneva Consensus Declaration On Promoting Women's Health and Strengthening the Family, Oct. 22, 2020, https://www.hhs.gov/sites/default/files/geneva-consensus-declaration-english.pdf and C-Fam, Statement of Austin Ruse, President of C-Fam, on the signing of the Geneva Consensus Declaration, Oct. 22, 2020, https://catholiccitizens.org/news/93078/statement-of-austin-ruse-president-of-c-fam-on-the-signing-of-the-genevaconsensus-declaration/.

${ }^{107}$ White House, Memorandum on Protecting Women's Health at Home and Abroad, Jan. 28, 2021, (providing for "timely and appropriate" withdrawal of U.S. co-sponsorship and signature from the GCD) and Letter to all Permanent Missions to the United Nations of signatories to the Geneva Consensus Declaration from the United States Permanent Mission to the United Nations, Feb. 19, 2021, https://c-fam.org/us-withdrawal-letter-to-gedsignatories-2-19-2021/ (notifying GCD signatories of U.S. decision to rescind "co-sponsorship and endorsement" of the GCD).
} 
in of an even tighter era of church-state integration. This will involve positioning the Church as the Kremlin's primary soft power instrument for building up Russia's international status as a norm arbiter and policy shaper, and as the deflector in chief of any criticism of Russian adventurism abroad. Consequently, policy makers should take note of the ROC's burgeoning foreign policy role and make necessary adjustments to account for the Church's increasing proximity to the Kremlin and its ongoing interaction and influence campaigns with governmental and non-governmental actors both here and abroad. 